\title{
Supply Chain Management for Superyacht Construction in Taiwan
}

\author{
Chun Pong Wong \\ Department of Shipping Technology, National Kaohsiung University of Science and Technology, cp@nkust.edu.tw
}

Follow this and additional works at: https://jmstt.ntou.edu.tw/journal

Part of the Fresh Water Studies Commons, Marine Biology Commons, Ocean Engineering Commons, Oceanography Commons, and the Other Oceanography and Atmospheric Sciences and Meteorology Commons

\section{Recommended Citation}

Wong, Chun Pong (2021) "Supply Chain Management for Superyacht Construction in Taiwan," Journal of Marine Science and Technology. Vol. 29: Iss. 5, Article 3.

DOI: 10.51400/2709-6998.2464

Available at: https://jmstt.ntou.edu.tw/journal/vol29/iss5/3

This Research Article is brought to you for free and open access by Journal of Marine Science and Technology. It has been accepted for inclusion in Journal of Marine Science and Technology by an authorized editor of Journal of Marine Science and Technology. 


\title{
RESEARCH ARTICLE \\ Supply Chain Management for Superyacht Construction in Taiwan
}

\author{
Chun Pong Wong
}

Department of Shipping Technology, National Kaohsiung University of Science and Technology, Taiwan

\begin{abstract}
In the last 20 years, Taiwan's superyacht construction industry has performed well in the global market; however, some yacht builders still practice traditional supply chain management (SCM), which is often inefficient and regularly leads to time and cost overruns. This study aimed to answer two research questions: 1) what SCM challenges does the superyacht construction industry face?, and 2) what SCM strategies and practices should be adopted to improve the efficacy and profitability of superyacht construction companies?

Numerous studies have explored supply chains (SCs) and SCM, but few have focused on the superyacht construction industry. Superyacht construction projects are highly complex and involve procuring numerous materials from different suppliers. Communication, negotiation, logistics, and control of such materials are considerably challenging but crucial for success.

The author worked in a superyacht construction company in Taiwan and helped convert its traditional SC to a modernized platform incorporating several corporate systems. Accordingly, this paper compares SCM theories and principles proposed in other studies through empirical observation and proposes 10 SCM strategies for the superyacht construction industry, including assessment of criticality for all materials, supplier relationship improvement, and policy implementation by corporate systems.

Recently, the superyacht construction industry has faced numerous difficulties, resulting in mergers, acquisitions, and restructurings. The demand for superyachts remains high, but sales are influenced by fluctuations in the global economy. This paper proposes strategies for alleviating SCM challenges and offers practical methods for reducing costs and increasing the profitability of superyacht construction projects.
\end{abstract}

Keywords: Superyacht, Shipbuilding, Supply chain management

\section{Introduction}

A superyacht is a privately owned yacht with a length of at least $24 \mathrm{~m}$ at the waterline. Recently, yachts have increased in size, and the term "megayacht" is often used to describe yachts measuring 60-180 $\mathrm{m}$ long. These definitions are not standardized and are often used interchangeably. Other qualifiers for superyachts or megayachts are that they are used for sport or pleasure rather than for carrying cargo or passengers commercially and are operated by a professional crew [27].
In addition to being symbols of industrial capability and excellence, the superyacht construction industry contributes substantially to the overall economy by supporting related industries, including harbor operations and services, tourism, engineering, design, and fashion [19,36].

North America is the largest yacht and superyacht market, followed by Europe; traditionally, the US and European yacht and superyacht construction industries are the largest in the world. However, yacht builders from Taiwan have recently increased their market share to approximately $6 \%$ of annual 
global tonnage of superyachts. Between 2010 and 2019, Taiwan ranked between fourth and eighth among the largest yacht and superyacht producers by tonnage, just behind countries such as Italy, the United Kingdom, Netherlands, Germany, and Turkey. During this period, average annual revenue for construction of yachts of length $>1500 \mathrm{~m}$ was US\$150 million. Studies conducted before the COVID-19 pandemic have indicated that large yachts were gaining popularity in Australian and Asian markets and that yacht-related quantity and revenue in these markets would increase $[2,13,38]$.

Superyacht construction is capital-intensive and is not suitable for start-ups with tight budgets for two reasons [11]. First, because superyachts are luxury products, marketing strategies must be sufficiently appealing to privacy-oriented customers with extravagant lifestyles. Second, construction contracts often present the following challenges:

- Securing funds for the yacht construction period that can take $2-5$ years, depending on the level of customization.

- In addition to funding, the yacht construction industry is susceptible to external environment changes such as global or regional economic downturns, currency fluctuations, variations in material and equipment costs, and labor shortages, all of which can affect the bottom line.

- Considerable raw materials, equipment, components, and fittings from different suppliers must be ordered, received, and assembled or installed at various stages of the yacht construction process, which requires strong coordination, a key function of supply chain management (SCM).

- Myriad stringent regulations from international shipping navigation authorities must be conformed to, including technical, operational, safety, and environmental requirements.

- During and after yacht construction, customers must be kept well informed and supported. Customers often dictate modifications at various stages of the construction process, resulting in additional challenges and complications.

Among these challenges, SCM is the most crucial responsibility of the yacht builder because it directly affects the quality of the finished product; the relationships with suppliers, subcontractors, staff, dealers, crew, and customers; the stability of funding; and profitability.

This study examined SCM components and practices of the superyacht construction industry on the basis of examples from Jade Yachts Inc.
(Taiwan), and SCM best practices are recommended for decision-makers in the superyacht construction industry.

This paper is organized as follows: Chapter 2 discusses key SCM concepts and theories according to relevant literature. Chapter 3 describes the methodology of this study. Chapter 4 describes and analyzes superyacht construction processes, SCM challenges, and potential strategies for superyacht builders. In addition, as a case study, Chapter 4 discusses the SCM strategies and practices adopted by Jade Yachts Inc. Finally, Chapter 5 summarizes the findings and recommendations.

\section{Literature review}

\subsection{Key elements of SCM}

A company's supply chain (SC) consists of suppliers that provide products, services, finance, and information. However, several studies have extended the scope of an SC to cover internal departments, subcontractors, outsourced personnel or companies, and customers. Through its SC, a company is able to purchase, assemble, stock, and sell its products or services to the intended market $[6,31]$. SCM is defined as the "design, planning, execution, control, and monitoring of supply-chain activities with the objective of creating net value, building a competitive infrastructure, leveraging worldwide logistics, synchronizing supply with demand and measuring performance globally" [23]. Essentially, SCM involves activities (e.g., designing, planning, execution, control, monitoring, logistics, information sharing, and communication) that create value (e.g., cost savings, profitability, supplier relationships, and customer service) $[28,29]$.

Several key concepts are distinguished in literature on modern SCM, namely leanness and agility strategies, base and surge demands, decoupling points, engineer to order, market qualifiers and market winners, and product lifecycle management (PLM).

In traditional SCM, a leanness strategy is adopted to minimize wastage, including undersold merchandise and overstocked goods. When applying a leanness strategy, a company maintains the minimum required stock and only requests goods when orders are placed. Thus, the company minimizes spending on stock, thereby minimizing costs on undersold stock as well as wastage in capital, warehousing, and human resources. However, compared with traditional SCM, this strategy requires customers to wait longer for goods that are in production or transit. Leanness is most effective 
when the key success factor is cost, demand is stable and predictable, variations are low, volume is high, and customers are indifferent to waiting for merchandise [7].

However, when demand is low, volatile, and unpredictable, and products highly variable, companies must be agile and flexible to produce results quickly and meet demand. In this strategy, the SC encompasses not only the internal organization but also the suppliers who share tasks, information systems, and logistics processes [7].

In the volatile and competitive commercial environment, numerous companies consider the most effective SC strategy to be a hybrid approach, namely a mix of lean and agile strategies ("legile") based on their needs [20,22]. To combine lean and agile strategies, Christopher [8] proposed a number of approaches. First is the Pareto curve, or the "80/20 rule." In this strategy, a company analyzes costs related to suppliers, parts or materials, and logistic options, and adopts a lean strategy for bulk items (i.e., approximately $80 \%$ of stock) and an agile strategy for generic or high-margin items (i.e., approximately $20 \%$ of stock).

The second proposed strategy is decoupling. In this strategy, only generic items are stocked (as with the lean approach), and when orders are placed (i.e., "decoupling points"), the items are assembled into the final products and subsequently delivered (as with the agile approach). Reportedly, HewlettPackard and other technology companies have employed this strategy.

The third proposed strategy involves the separation of base and surge demands. Base demand is forecast on the basis of past results, whereas surge demand is the amount of demand beyond predicted. In this strategy, the items are stocked to meet base demand with a lean approach, and additional items are stocked to meet surge demand with an agile approach $[9,12,21,25,38]$.

In the era of globalization and "network competition," companies that can more effectively manage the flow of materials, information, and services with their "networked" suppliers or partners can provide better value in the marketplace. "Networked" alliances can be established by selecting "like-minded" strategic suppliers, sharing quality information through reliable systems, and establishing multiple collaborative work relationships between organizations at all levels $[1,8,30]$. When developing SC relationships with selected suppliers, all involved decision-makers must be trustworthy and committed, and the ensuing collaboration must be mutually and reciprocally beneficial. With a high level of trust and commitment, the involved parties are more likely to exchange sensitive and proprietary information to improve SC performance [32].

Another corporate system that complements SCM is PLM, which allows customers, designers, developers, staff, and suppliers to share data, processes, and information systems, helping them to collaborate on product lifecycle issues, namely concept, design, supply, production, application, service and maintenance, and end-of-life. Data and process sharing provides insights into the SC, and collaboration among stakeholders enables faster and better-informed logistics and business decisions [3]. Advancements in cloud data sharing, Internet of things, and artificial intelligence will continue to influence innovation in collaboration among SCM, PLM, and other business systems for many years.

Another trend involving environmental and ethical concerns in SCM has emerged. Manufacturers and businesses are now expected to share social responsibility by considering the environmental impact of their business operations, namely design, production, delivery, stock, service, and disposal of goods after expiration [33].

\subsection{SCM in the shipbuilding industry}

A ship is essentially a combination of a large vehicle and a building; it carries cargo, crew, and passengers, and moves across water to serve one or more purposes, including cargo transportation, fishing, ferrying, and leisure. As such, shipbuilding involves numerous disciplines and technologies. Throughout each phase of a shipbuilding project, namely contract negotiation, prefabrication, fabrication, interior construction, fit-outs, and commissioning, numerous stakeholders, including customers, designers, suppliers, outsourcing contractors, and staff, contribute knowledge, skills, specifications, parts, or products.

The construction costs and sale prices of ships are high, and demand is unpredictable. In addition, many parts are unique, and ships typically require few such parts, whereas the standards for quality and timing of delivery are high. Such factors lead to complications with procuring materials, parts, and components, and fostering relationships with key suppliers. During shipbuilding, a substantial amount of diverse information is generated, communicated, applied, modified, and recommunicated, resulting in additional complications in SCM.

In the shipbuilding industry, every ship is an individual project, and as such, SCM should be 
project-oriented rather than manufacturing-oriented. There is no base demand, and the timing of each sale is somewhat unpredictable. In terms of SC strategies, lean operations and module-based manufacturing are not practical. Decoupling points are most likely to be downstream (close to the customers), resulting in high costs and long lead times.

Therefore, most shipbuilders focus on their internal capabilities and outsource between $60 \%$ and $80 \%$ of the total value of a ship to other suppliers and service providers, often forming a shipbuilding SC network. For this reason, some shipyards are referred to as assembly shipyards rather than fullfledged shipyards. In the current superyacht construction industry, the skills and abilities required to coordinate activities and build relationships with suppliers and outsourcing partners to form an integrated network determine the success and profitability of a shipbuilding project [18].

Because SC involves a multitude of employees, contractors, subcontractors, outsourced workers, suppliers, and customers representatives, information on design, assembly, configuration, production, and other issues must be generated and shared appropriately. Mello and Strandhagen [18] emphasized that information and communications technology (ICT) is crucial for coordinating activities, interacting with suppliers, and building intercompany teams, as well as being a critical component in the shipbuilding SCM.

\subsection{SCM in the yacht and superyacht construction industry}

Ponticelli et al. [22] compared the SCM practices of four Italian yacht construction companies by interviewing their directors and key management personnel. The number of people employed by these companies ranged from 270 to 1100 , and their annual turnover in 2012 ranged from $€ 75$ million to $€ 450$ million. The researchers categorized the SCM strategies of these companies as postponement, concurrent engineering, codesign, ICT integration, network coordination, and SC member selection.

Although customers typically want their yachts to be designed according to their personal preferences, yacht builders practice "postponement" to defer SC decisions until the last possible moment. In this strategy, specifications and stocked items are deliberately kept generic, and components are assembled into final products only when customers' demands are confirmed. This practice is most common in the interior construction and furniture fit-out stages; for example, the company stocks generic furniture and applies modifications only when the customer makes a decision. Through postponement, companies have additional time to modify products to meet customers' demands. In addition, numerous yacht builders design fit-out modules to improve production efficiency and reduce production lead time and costs.

In addition to postponement, some yacht builders construct high-quality yachts according to generic specifications before a sale is secured. In this strategy, construction is performed slowly until a buyer is found. The purpose of this strategy is to attract customers who are eager to get on the water.

Concurrent engineering involves two or more teams working simultaneously on different aspects of the same project. Accordingly, codesign requires relevant SC members to design certain parts of a project collaboratively. For example, through an IT platform, the customer, interior designer, subcontractor, and shipbuilder can collaborate to expedite the design process for interior fit-outs. Both concurrent engineering and codesign improve efficiency and reduce lead time and costs.

ICT integration and network coordination are collaboration systems based on computer hardware and software and network connectivity. Often, the shipbuilder plays the part of a project manager to coordinate activities performed by other SC members. For these systems to be effective, a concerted effort must be exerted toward policies, procedures, training, coordination, and performance appraisals, and management analysis must be performed continually to make improvements.

SC members that do not perform as required contribute to losses in time, cost, relationships, reputation, and customer confidence in the company. Therefore, yacht builders must select suppliers through a rigorous process based on criteria including quality, advisory capabilities, price, and level of support [22].

Superyachts are larger, more luxurious, more complex, and more expensive than regular yachts. Therefore, although SCM for superyacht construction is substantially similar to SCM for regular yacht construction, some variations exist:

a. Degree of customization. Superyachts tend to be highly customized with unique fit-outs. Although customization is a key feature of superyacht construction, superyacht builders must be able to mitigate the unpredictability and extra costs resulting from changes to designs at later stages of construction process.

b. Size, scale, and capability. Because superyachts are essentially "enhanced" versions of regular yachts, SCM is much more challenging, and 
strategies such as postponement, collaboration, ICT integration, supplier relationship development, and quality control must be employed more effectively.

\subsection{Superyacht construction in Taiwan}

According to statistics from Boat International, in 2019, Italian yacht builders produced the highest total length of superyachts $(14,374 \mathrm{~m})$, followed by yacht builders in Netherlands, Turkey, the United Kingdom, Germany, and Taiwan. With a total length of $1852 \mathrm{~m}$ and an annual revenue of more than US\$230 million, Taiwan ranks sixth globally and first in Asia. Taiwanese yacht builders, Alexander Marine and Horizon, ranked seventh and ninth, respectively, among the top 20 yacht builders globally. The largest market for Taiwanese yacht builders was the United States $(68.7 \%)$, followed by Australia (13.8\%), Italy (3.7\%), and Japan (2.6\%) [27].

Merendino et al. [19] analyzed the efficiency scores of top-ranking superyacht builders through data envelopment analysis and compared the superyacht builders' financial ratios, including profitability, activity/turnover, liquidity, and leverage/solvency. The researchers observed that before and during the 2008 global financial crisis (GFC), Italian superyacht builders were top-ranked and had efficiency scores similar to those of yacht builders from other countries. However, in the post-GFC era, the efficiency scores of Italian superyacht builders decreased, signifying that although they were productive, they were not as profitable as superyacht builders from countries such as the United Kingdom and Germany.

For yacht builders to improve their efficiency scores, they should adopt corporate systems as discrete elements of or complements to existing aspects of SCM. Specifically, superyacht builders should adopt strategies such as PLM, which enables collaboration among staff, customers, suppliers, and contractors; customer relationship management (CRM), which aids communication with customers; and enterprise resource planning, which helps resource management within the company. Each system helps to improve the financial ratios and profitability of superyacht builders in the current global competitive environment $[16,19]$.

Yacht builders in Taiwan have survived the challenges of global competition and the 2008 GFC. The resilience of the industry relies on factors such as entrepreneurs who are not afraid to apply bold, rigorous strategies to fine-tune their operations; a thriving manufacturing-based economy that supports small to medium-sized businesses; and suppliers that form business clusters in various industries, including shipbuilding, technology, and semiconductor manufacturing [36].

\section{Research methods}

The author worked at Jade Yachts Inc., Kaohsiung, Taiwan, from 2004 to 2020, in various managerial positions including sales, procurement, and construction management, and reported to the company Chairman and other key personnel. As a qualified ship captain with more than 20 years of commercial piloting experience, the author was involved in commissioning tests, sea trials, and assessments and quotations for yacht maintenance and refit projects. He was responsible for or supported the introduction of several corporate SCM systems, including a manufacturing execution system (MES), CRM, and PLM.

After assuming a teaching position at National Kaohsiung University of Science and Technology (NKUST), the author resigned from Jade Yachts Inc. to focus on teaching and research. However, he remains involved in an industry-academia collaboration plan between Jade Yachts Inc. and NKUST and is a member of the Technical Development Committee of the Taiwan Yacht Industry Association, a committee that aims to enhance the efficacy and technological development of yacht manufacturing. The author applied his experience to the current study, which adopts a qualitative research method involving literature review and participant observation $[4,14,15,17,26,35]$.

The current study begins with a literature review of SCs and SCM in general industries and in the yacht and superyacht construction industry. The review compares and analyzes the principles and theories of SCM with the SCM models and practices adopted by Taiwanese yacht builders, including Jade Yachts Inc., to determine SCM strategies and practices to address the two aforementioned research questions:

RQ1: What SCM challenges does superyacht construction industry face?

RQ2: What SCM strategies and practices should be adopted to improve the efficacy and profitability of superyacht construction companies?

\section{Results}

\subsection{Superyacht construction process}

The activities and the materials, equipment, and parts required for each stage of the process, as shown in Fig. 1, are described as follows: 


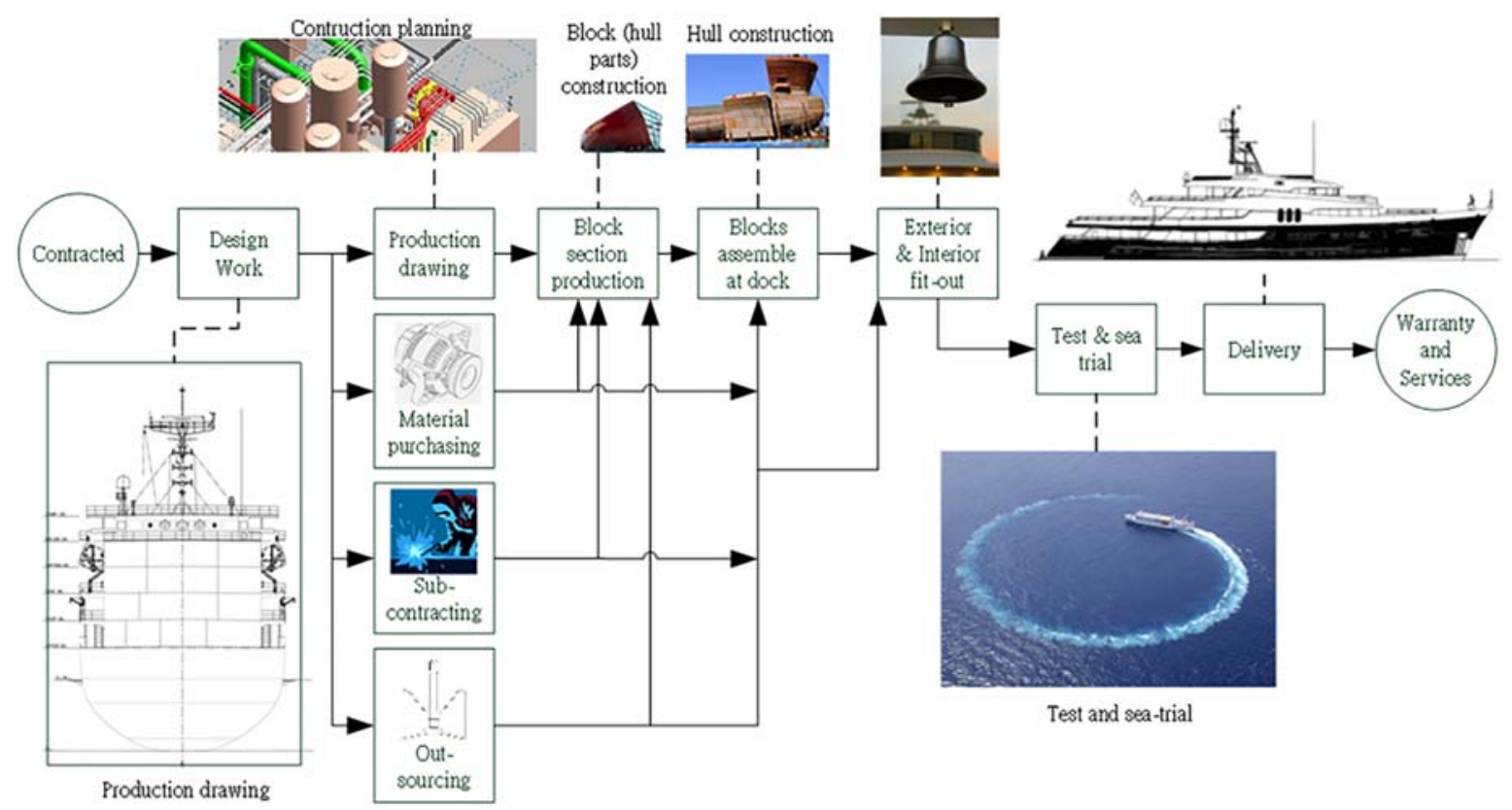

Fig. 1. Typical superyacht production process.

a. A number of specialized design firms that dominate the superyacht market are capable of designing superyachts that meet international navigation and safety standards and performance requirements. In general, during the design stage, a superyacht builder collaborates with a design firm designated by the customer in the purchase contract, which stipulates all design specifications, including dimensions, structure, aesthetics, navigation functions, hull materials, superstructure, and exterior and interior fit-outs, together with detailed structural drawings.

b. In the construction planning stage, individual suppliers preorder and schedule deliveries for key equipment including engines, rudders, shafts and propellers, generators, windlass winches and anchor systems, watermakers, life rafts, and electronic systems (e.g., radar, GPS, computers, and communications and navigation systems). Items such as raw materials, special tools, and fitting materials and parts, totaling tens of thousands of stock items, must be ordered, scheduled for delivery and warehousing, and booked out for construction.

c. During the construction stage, two key phases must be completed before the yacht can be commissioned and delivered; that is, block construction for the hull and superstructure and exterior and interior fit-outs, which are described as follows:

i. For block section production and assembly, fiber-reinforced plastic (FRP) is typically used in the hull blocks of small yachts, whereas steel and aluminum alloy are typically used in the hull and superstructure of most superyachts.

ii. According to the contract, navigation, maneuvering, and operations equipment, including engines, power generation systems, and nautical instruments, are preordered.

iii. After the yacht's hull has been constructed, items such as engines, generator systems, piping, and cabling are fitted, after which deck work and other fittings are applied. In this phase, groups of technicians, engineers, and tradespersons (e.g., ironsmiths, carpenters, plumbers, electricians, tilers, and painters) must be scheduled to work on items such as materials, furniture, decoration, and sanitary ware and equipment. In addition to employees, numerous subcontractors and outsourced workers all work separately onsite $[10,34,35]$.

iv. After fit-outs are in place, items such as electronic navigation devices, cockpit equipment, furniture, and safety apparatuses can be fitted and thoroughly tested.

d. In the commissioning stage, the superyacht is lowered into the water for testing. After the ship passes all tests and is certified according to the relevant standards and regulations of the International Maritime Organization and International Association of Classification, the ship's license is granted [34,35]. 
e. During the construction stages, customers commonly request changes to the contract and start negotiations on construction modifications, which affect the SCM.

f. After the yacht is delivered, warranties and support services are typically offered for several years, and the company must maintain or procure equipment and parts as required.

\subsection{SCM challenges in the superyacht construction industry}

In any industry, SCM is a core activity affecting product quality, delivery timing, customer satisfaction, staff skill and reliability, subcontracting and outsourcing, supplier and subcontractor relationships, and, most importantly, profitability.

As described in Subsection 3 of Section II, the construction of a superyacht can be just as complex as the construction of a building. The SCM challenges involved in superyacht construction projects are described as follows:

a. A superyacht requires a large variety of equipment, materials, parts, and components, typically totaling tens of thousands of items, which often have unique specifications, prices, and required-by dates and times.

b. Numerous suppliers from various disciplines, such as metallurgy, machinery, electrical and electronics, petrochemical, and hardware, are involved in construction. These suppliers often have their own processes, systems, contact representatives, and terms and conditions. In addition, many items are provided by upstream suppliers; thus, if an upstream supplier fails to deliver an item, then downstream suppliers may not be able to supply materials as required.

c. Certain items may be bulky or oddly shaped such that special freight services are required to transport them. Other items may require special treatment during transit or storage to meet relevant requirements and regulations.

d. International currency exchange rates may fluctuate during the construction period, making it difficult to follow an established budget.

e. Logistics may be unreliable because of unpredictable delays due to events such as supply and demand variations, natural disasters, sanctions, wars, strikes, and other unforeseeable issues. When any such issue occurs, flow-on issues arise, labor and production costs increase, and the project is delayed. f. Developing relationships with suppliers requires time, effort, and skills. Issues involving trust, mutual understanding, costs, and resources may arise, requiring the company and the suppliers to negotiate.

g. Contracting and financing certain purchases may be complex because suppliers may have different terms and conditions for payment methods. In addition, many items must be individually inspected and negotiated for.

h. Collecting, entering, and sharing SC data is sufficiently challenging within an organization, and doing so with multiple companies can be even more challenging. In addition, some data are commercially sensitive, and nondisclosure agreements may not always ensure data security.

i. Many parts and components must comply with international shipping regulations and standards. Some issues with quality may not arise until fitting or installation. By then, requesting service or a refund or reordering and replacing the affected component may be very challenging.

j. Warehouse and stock management is complex, as is receiving, safekeeping, transferring for assembly, returning, and the myriad other tasks required for the potential tens of thousands of items involved in a superyacht construction project.

\subsection{SCM strategies for the superyacht construction industry}

Although SCM for superyacht construction projects may be challenging, SCM strategies offer numerous advantages, providing superyacht builders with the following benefits:

a. Cost savings in construction

b. High-quality superyachts

c. More satisfied customers and better relationships with customers

d. Better relationships with suppliers

e. More loyal employees, subcontractors, and outsourced workers

Crucially, superyacht construction companies can increase profits by implementing SCM strategies $[18,19]$.

To overcome the challenges of superyacht construction SCM described in Subsection 2 of Section IV, companies should employ the following strategies: 
a. Establish standard operating procedures for inquiring, ordering, receiving, stocking, booking out, and payment.

b. Anticipate unpredictable changes to orders and manage budgets accordingly.

c. Order a certain percentage of extra stock as a buffer according to the potential risk of disruption and unanticipated costs due to the unexpected deferment of such items.

d. Invest in ICT and corporate systems such as an MES, CRM, PLM, and a warehouse management system (WMS). In addition, platforms such as cloud services, 4G and 5G mobile and Wi-Fi networks, and virtual private networks (VPNs) should be maintained and optimized.

e. Invest in staff and supplier training, as any system is only as good as the people operating it.

f. Implement data security procedures that are proportional to the importance of the data or the assessment of potential losses in the event of a breach.

g. Select suppliers according to criteria such as capability, product quality and reliability, willingness to cooperate, price, logistics (if initiated by them), and support level. Nurture supplier relationships with those who are reliable, and replace those who are not.

In terms of detailed SCM implementation, companies should consider the following practices:

a. Classify each stock item according to criticality and risk level as well as the potential cost of an alternative if the item becomes unavailable for a period of time. Ensure a percentage of item stock or alternative stock as a buffer according to assessments of quantity, time, and cost.

b. Form relationships with alternative suppliers at different tiers. At the start of the COVID-19 pandemic, many countries were incapacitated when upstream supplies of personal protective equipment such as masks were unexpectedly disrupted, and downstream manufacturers could not meet the demand, causing supply shortages and numerous severe consequences.

c. Monitor the performance of logistics service providers and evaluate their efficiency and cost. Allocate time and exert effort to foster relationships with high performers. Communicate effectively and consistently. If a supplier or freighter is unreliable, do not hesitate to replace them because a weak connection in the SC is a weak connection in the business.

d. Invest not only in corporate software packages but also in procedures and training for data entry, sharing, and interpretation in parallel with each corporate system. A good system requires good operators and procedures.

e. Be vigilant on data sharing platforms because sensitive data can make or break a business and cause visible or invisible losses. On the basis of the sensitivity of the data, set access privileges for each individual.

f. Verify the quality and performance of all parts because retrofitting can be expensive, if not detrimental, to a project.

g. Regularly review stock levels and performance, assess warehousing policies and costs, and determine whether built-in elasticity and leeway are sufficient.

h. Request suppliers to participate in and comply with data entry and format, and offer rewards or ongoing orders when they conform.

i. Establish processes for assessing SCM performance. Consider the contribution or value of the SC overall, and compare it against the cost and effort required to maintain the system.

j. Suppliers for large corporations may request compliance with their data entry systems. Participate diligently in such operations because this will assist in relationship building, benefitting both sides.

\subsection{Jade Yachts Inc.: a case study}

Established in 2004, Jade Yachts Inc. is a subsidiary of Jong Shyn Shipbuilding Co. Ltd, which was incorporated in 1985 and operates five dockyards totaling $140,000 \mathrm{~m}^{2}$, has constructed thousands of deep-sea fishing vessels, coast guard patrol boats, ferries, and tug boats. In 16 years of operation, Jade Yachts Inc. has constructed superyachts for numerous customers, including Moët Hennessy Louis Vuitton, the French conglomerate of luxury goods, and several other renowned European corporations. In addition, Jade Yachts Inc. has also won dozens of refit and maintenance contracts for superyachts. As of 2020, Jade Yachts Inc. has more than 300 employees.

The author was an employee at Jade Yachts Inc. for 16 years, and since his resignation in 2020, has been a participant in an industry-academia collaboration plan between Jade Yachts Inc. and NKUST, where he teaches. With the permission and support of the company's decision-makers, the SCM system used by Jade Yachts Inc. is described subsequently as a case study; no sensitive details have been disclosed.

Fig. 2 presents the data flow for internal and external SCM participants for Jade Yachts Inc. as follows: 
a. Each department is responsible for data entry and processing.

b. External participants (e.g., suppliers and contractors) receive orders with specifications and update the WMS as they supply the warehouse. The internal staff then enter the relevant data into the SCM database.

c. The SCM database consists of the WMS, MES, CRM, and PLM, and interfaces with other corporate software packages used by each department.

Fig. 3 presents the relationship and functions of the corporate systems as follows:

a. Solid arrows indicate actual data flows among interconnected packages and external suppliers, and the dashed arrows indicate the one-way flow of production data after a transmission is authorized.

b. Data generated from various systems are entered into the SCM system for regular analyses and assessments.

c. Cloud services and VPN connections are employed to enable remote access by personnel in different departments and by external suppliers. d. External participants are only allowed to interact with the purchase and warehouse systems.

After the SCM system was implemented, the challenges related to SC unreliability were mitigated, and additional features and benefits were obtained:

a. Construction personnel could retrieve design details on-site; with three-dimensional simulations produced by the computer-aided design systems, the accuracy and correctness of the work could be determined in-hand.

b. Warehouse staff could compile details of each purchase order, including quantity, type, expected delivery time, actual arrival time, inspection and acceptance, required-by time, and actual booking out time.

c. Finance staff could examine the accuracy, timeliness, and other performance parameters of suppliers.

d. The MES managed automated production at the yacht body construction stages, minimizing error and wastage.

e. For each stock item, data such as standards, specifications, pricing, classifications, required-

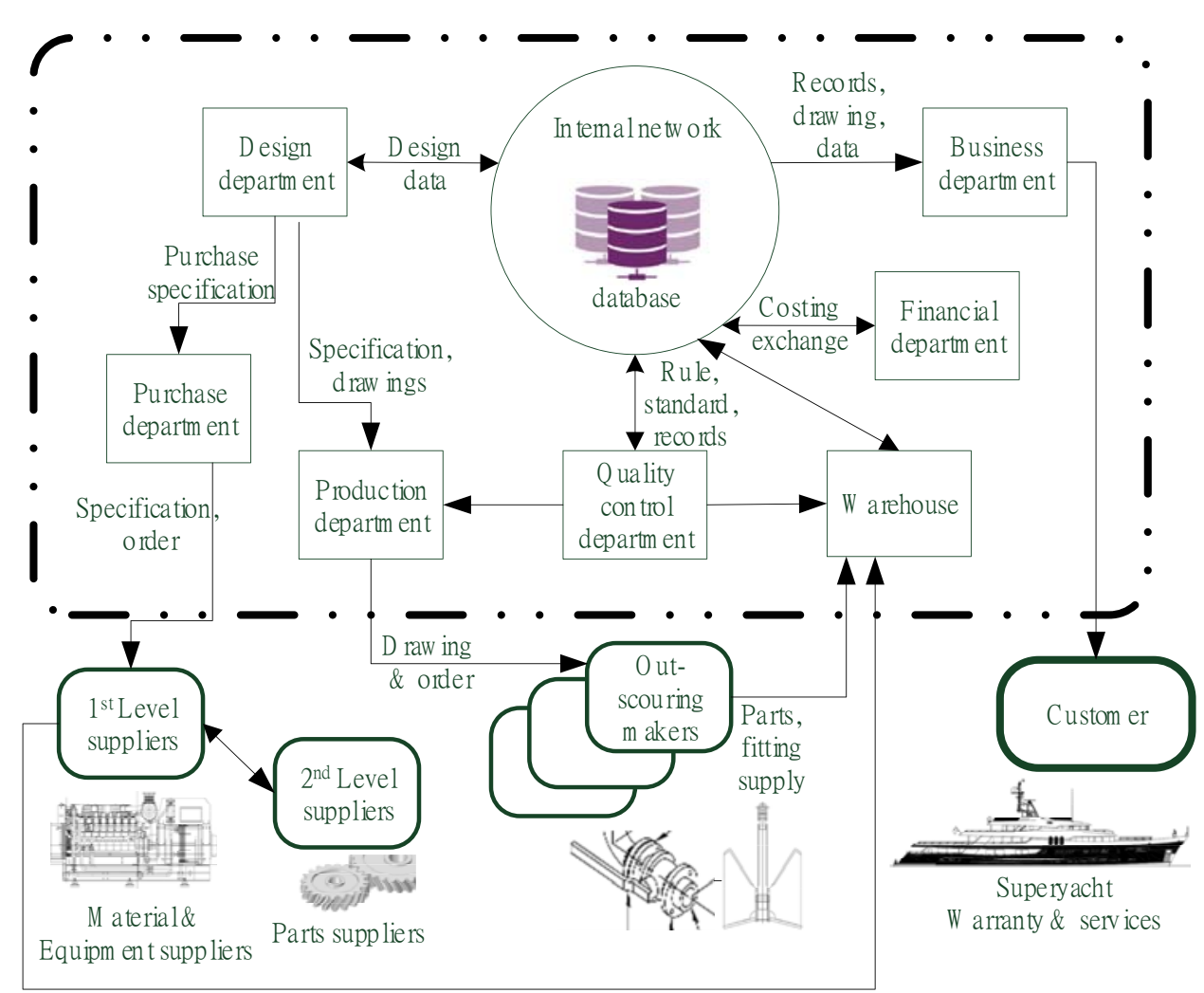

Fig. 2. Data flow for internal and external SCM participants for Jade Yachts Inc. 


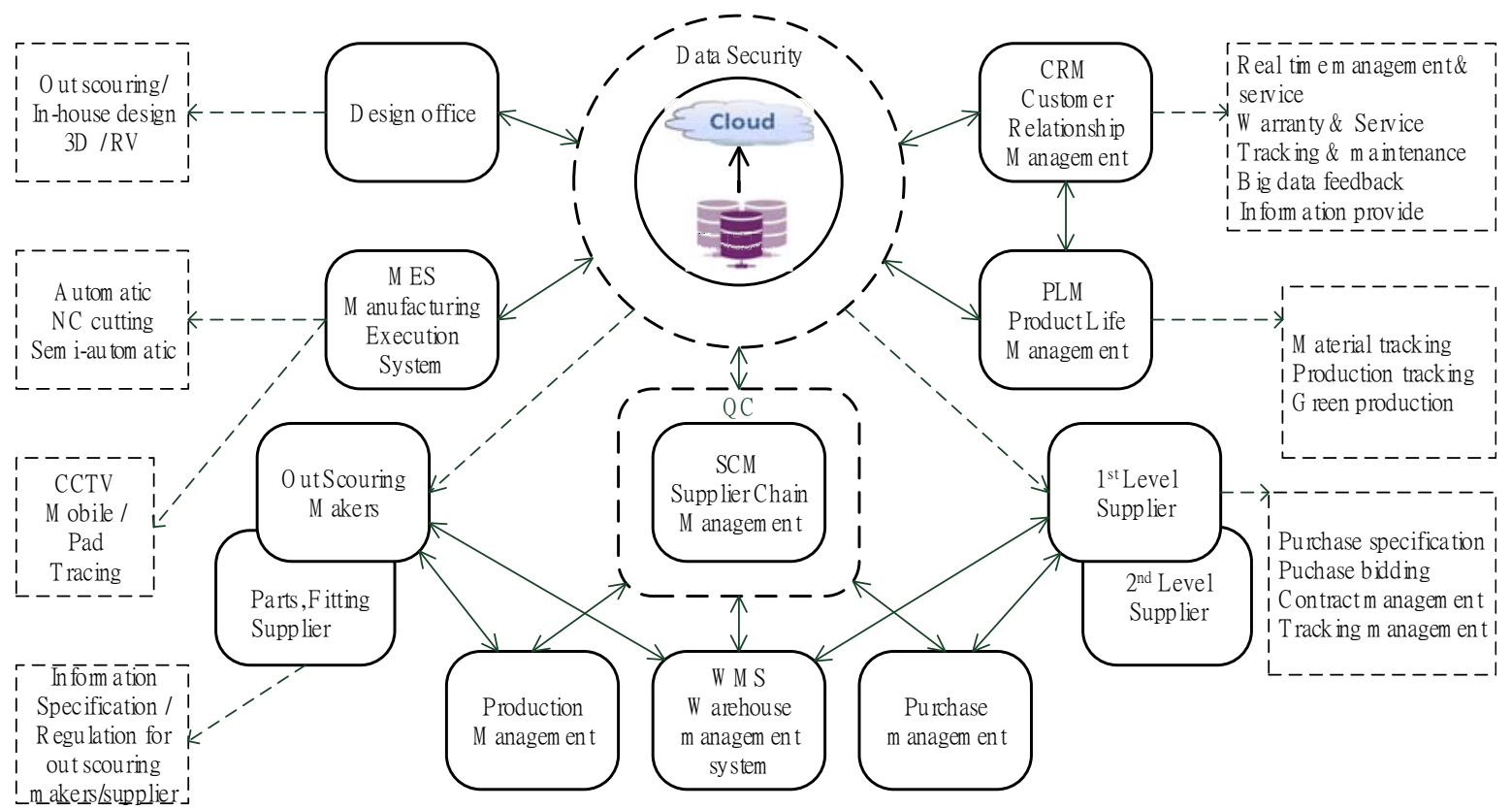

Fig. 3. Relationships and functions of software-based packages.

by times, means of transportation, terms and conditions, warranty periods, and user manuals were entered into the system to enable comparison of accuracy and reduce double ordering and handling. This led to a reduction in wastage and warehouse and stocking mistakes.

f. SCM and production data including design drawings, construction data, warehouse item quantities and locations, and booking out of stock items enabled staff in design and production departments to more effectively manage projects and schedules.

g. When changes were made to the contract between the company and the customer, related suppliers would be informed promptly (after the data were authorized for release).

h. Business (sales and marketing) department staff could more effectively estimate and present costs and pricing for product (superyacht) features and specification variations.

i. With accurate historical data and incident reporting, the company could provide more effective training for staff, subcontractors, and outsourced workers, thereby improving occupational safety and reducing risks of workrelated accidents.

j. With better cost data and more precise specifications, negotiating with outsourcing partners to strike balanced and mutually beneficial agreements was more straightforward.

\section{Discussion and conclusion}

In 1970s, during the Vietnam War, some US military service personnel visited Taiwan, and before the end of the war, some discovered that small shipbuilders in Taiwan could produce yachts at prices very competitive to those of yachts in the United States. They began placing orders and sharing knowledge with these ship builders; through this turn of events, the yacht construction industry in Taiwan began to flourish. Currently, Taiwan has a thriving yacht and superyacht industry. However, compared with luxury superyacht builders in Western Europe, most Taiwanese yacht builders still adopt traditional SCM strategies and continue to perform original equipment manufacturing of FRP yachts up to $45 \mathrm{~m}$ long for European and US brands.

This study examined the challenges of and strategic options for SCM in the superyacht industry in Taiwan, and aimed to answer the following two research questions:

RQ1: What SCM challenges does the superyacht construction industry face?

RQ2: What SCM strategies and practices should be adopted to improve the efficacy and profitability of superyacht construction companies?

The literature review on SCM indicated several mainstream SCM theories. First, the concept of agile and lean SC and production processes are pertinent, 
and a balance between the two styles according to the type of operation must be reached. Second, decoupling points in the SC can be explored to determine the most effective SC strategies and practices. Third, comparative analyses of market qualifiers and market winners can identify the most effective SCM approaches a company can apply $[9,20,21]$.

Superyachts, often termed "billionaires' toys," are considered luxury goods. Superyacht sales are rare, and contract negotiations typically require a considerable amount of time to finish. In addition, the design and construction of superyachts can be highly customized, and construction time can be extensive [11]. Furthermore, the SCM challenges (RQ1) related to the sheer number and variety of products are exacerbated by issues related to logistics and suppliers (Subsection 2 of Section IV).

A properly planned and managed SC can mitigate the challenges and generate numerous benefits, including improved customer service, reduced inventory and operating cost, improved customer satisfaction, and enhanced profitability [3]. Subsection 3 of Section IV suggests SCM strategies and practices for superyacht builders, including implementing internal procedures for managing stock, establishing alternative items and suppliers, investing in corporate systems, and fostering and maintaining supplier relationships.

The case study presented in Subsection 4 of Section IV provides a general description of the SCM that Jade Yachts Inc. adopted for their operations. Jade Yachts Inc. is one of the few yacht builders in Taiwan to invest substantial resources in and exert effort toward developing its SCM systems to compete with the large, reputable superyacht builders globally. Jade Yachts Inc. has made several achievements, but the 2008 GFC and the 2020 COVID-19 pandemic prompted the company to focus on refitting and maintaining of superyachts instead of constructing new ones. Despite market fluctuations, the comprehensive and sophisticated SCM that Jade Yachts Inc. has developed indicates that the company is in a strong position to adopt, compete, and succeed in the global marketplace. Similarly, for other superyacht builders to grow and progress, they must form strategies, invest in resources, and implement modern SCM practices.

Furthermore, industries are expected to follow the trend of reducing their environmental impact. Systems that reinforce green values, including sustainable SCM, service-dominant logic, and PLM, all help companies to benefit from increased awareness of natural resource sustainability and environmental conservation $[5,24]$. However, the practices, benefits, and costs involved with these concepts are not well-defined; therefore, the environmental sustainability of SCM in superyacht construction is a potential topic for future research.

Another pertinent topic is the competitiveness of superyacht companies in countries such as Taiwan relative to market leaders in Western Europe and North America. In the era of globalization, the superyacht construction has not shifted to countries with lower labor costs, such as Brazil, Russia, India, and China, perhaps because the quality and technological requirements of superyachts are prohibitively high, and only countries with advanced shipbuilding infrastructures and clusters of vertically integrated suppliers can compete. This topic may also be worthy of future research.

\section{Conflict of interest statements}

The author has no conflicts of interest to declare, and no financial support was received for this study.

\section{Acknowledgments}

The author expresses his deep gratitude to $\mathrm{Mr}$. Pihsiang HAN, the Chairman of Jade Yachts Inc., for providing invaluable opportunity, guidance, and leadership to allow the author to work, learn, grow, and contribute to the success of the company. Furthermore, the author wants to thank the management team in Jade Yachts Inc. for allowing him to use the SC that he was involved in setting up as a case study for this paper. Special thanks are given to Mr. Edward Wechner, Mr. Ming Leu, and Mr. Tom Stolaski (Wallace Academic Editing) for their contributions in proof reading this article.

\section{References}

[1] de Vries J, Aronsson H, Abrahamsson M, Spens K. Developing lean and agile health care supply chains. Supply Chain Manag: An Int J 2011;16(3):176-83.

[2] Boat International. Global order book. Boat International; 2019. p. 2020. Retrieved from, https://www.boatinternational. com/yacht-market-intelligence/luxury-yachts-on-order/ 2020-global-order-book-42403.

[3] Bouhaddou I. PLM for supply chain optimization. Product Lifecycle Management-Terminology and Applications; 2018. https://doi.org/10.5772/intechopen.81272. Retrieved from.

[4] Brancheau JC, Brown CV. The management of end-user computing. ACM Comput Surv 1993;25(4):437-82.

[5] Carter CR, Easton PL. Sustainable supply chain management: evolution and future directions. Int J Phys Distrib Logist Manag 2011;41(1):46-62.

[6] Cavinato JL. What's your supply chain type? Supply Chain Manag Rev 2002;6(3):60-6.

[7] Christopher M. The agile supply chain: competing in volatile markets. Ind Market Manag 2000;29(1):37-44.

[8] Christopher M, Gattorna J. Supply chain cost management and value-based pricing. Ind Market Manag 2005;34(2): 115-21. 
[9] Christopher M, Towill D. An integrated model for the design of agile supply chains. Int J Phys Distrib Logist Manag 2001; 31(4):235-46.

[10] Chuang S. Taiwan's yacht industry sailing well toward promising sea. 2015. Retrieved from, https://www.cens.com/ cens/html/en/news/news_inner_47883.html.

[11] Ferreira FAL, Scavarda LF, Ceryno PS, Leiras A. Supply chain risk analysis: a shipbuilding industry case. Int J Logist: Res Appl 2018;21(5):542-56.

[12] Gligor DM. The role of demand management in achieving supply chain agility. Supply Chain Manag: Int J 2014;19(5/6): 577-91.

[13] Hodgson C. The number of super-rich 'ultra-high net worth' people is growing. UK: Business Insider; 2017. Retrieved from, http://uk.businessinsider.com/wealth-x-super-richreport-increase-inwealth-number-of-ultra-wealthy-2017-6.

[14] Huang JY. Enterprise research. Taipei: Taiwan Tung Wah Group; 1999. p. 19-26.

[15] Jorgensen DL. The methodology of participant observation. Participant observation: A methodology for human studies; 1989. p. 12-25.

[16] Kuah CT, Wong KY, Behrouzi F. Application of data envelopment analysis to assess quality management efficiency. World Acad Sci Eng Technol 2010;4(10):651-6.

[17] McCall GJ, Simmons JL, editors. Issues in participant observation, reading, mass. Boston: Addison-Wesley; 1969. Ch.4,5,8.

[18] Mello MH, Strandhagen JO. Supply chain management in the shipbuilding industry: challenges and perspectives. Proc IME M J Eng Marit Environ 2011;225(3):261-70. https:// doi.org/10.1177/1475090211406836. Retrieved from.

[19] Merendino A, Gagliardo ED, Coronella S. The efficiency of the top mega yacht builders across the world: a financial ratio-based data envelopment analysis. Int J Manag Decis Making 2018;17(2):125. https://doi.org/10.1504/IJMDM. 2018.092544. Retrieved from.

[20] Myerson PA. A lean and agile supply chain: not an option, but a necessity. SP Jain School of Global Management; 2014. Retrieved from, https://www.coursehero.com/file/19340541/ A-Lean-and-Agile-Supply-Chain/.

[21] Naylor JB, Naim MM, Berry D. Leagility: integrating the lean and agile manufacturing paradigms in the total supply chain. Int J Prod Econ 1999;62(1-2):107-18.

[22] Ponticelli S, Mininno V, Dulmin R, Aloini D. Supply chain implications for one-off luxury products: cases from the yacht industry. Int J Retail Distrib Manag 2013;41(11/12): 1008-28.
[23] Rice S. The total scope of supply chain management. 2015. Retrieved from, http://www.apics.org/sites/apics-blog/ thinking-supply-chain-topic-search-result/thinking-supplychain/2015/03/11/the-total-scope-of-supply-chainmanagement.

[24] Schaltegger S, Burritt R. Measuring and managing sustainability performance of supply chains. Supply Chain Manag: Int J 2014;19(3):232-41.

[25] Sebastiao HJ, Golicie S. Supply chain strategy for nascent firms in emerging technology markets. J Bus Logist 2008; 29(1):75-91.

[26] Spradley JP. Participant observation. New York: Holt Rinehart \& Winston; 1980.

[27] Springer B. What makes A superyacht A superyacht? Boats \& Planes; 2019. Retrieved from, https://www.forbes.com/ sites/billspringer/2019/08/07/what-makes-a-superyacht-asuperyacht/?sh $=7343641 \mathrm{c} 71 \mathrm{c} 6$.

[28] Stevens GC. Integrating the supply chain. Int J Phys Distrib Mater Manag 1989;19(8):3-8.

[29] Stevens GC, Johnson M. Integrating the supply chain ... 25 years on. Int J Phys Distrib Logist Manag 2016;46(1):19-42.

[30] Su SI, Gammelgaard B, Yang SL. Logistics innovation process revisited: insights from a hospital case study. Int J Phys Distrib Logist Manag 2011;41(6):577-600.

[31] Sundara MS. Understanding shipbuilding supply network. Asian J Res Bus Econ Manag 2017;7(3):107-13.

[32] Tsanos CS, Zografos KG. The effects of behavioural supply chain relationship antecedents on integration and performance. Supply Chain Manag: Int J 2016;21(6):678-93.

[33] Tsoulfas GT, Pappis CP. Environmental principles applicable to supply chains design and operation. J Clean Prod 2006; 14(18):1593-602.

[34] Wong CP. Analysis of the characteristics of shipbuilding industry in Taiwan. J Mar Technol 2008;1:37-80.

[35] Wong CP. Analysis of yacht industry growth in Taiwan. In: International symposium on marine science and technology 2009. Kaohsiung: NKMU; 2009.

[36] Yan HD. Taiwan's yacht industry: a tale of two entrepreneurial firms. Global Econ Rev: Perspect East Asian Econ Ind 2008;37(4):469-86.

[37] Yang YC, Liu HP. Determinants of banking sector's credit granting policy for the yacht industry in Taiwan. Marit Bus Rev 2016;1(1):55-75.

[38] Zheng JC, Li YS. Tactics selection on lean M.F and agile M.F. J Beijing Jiaot Univ 2004;3(2):29-32. 